\title{
Dignified and Picturesque: Redpath Library in 1893
}

\author{
by Peter F. McNally
}

Redpath Library figures prominently in the history of both McGill University and Canadian librarianship. When it opened on October 31,1893 it was only the second free-standing academic library in the country and one of the half-dozen buildings on the University's campus. Through the generosity and wisdom of its benefactor, Peter Redpath, and the taste and talent of its architect, Andrew Taylor, the building is a masterpiece of late Victorian design and an outstanding example of contemporary library planning. Redpath and Taylor are placed within their historical contexts to show how their collaboration resulted in a library which is a remarkable blend of Canadian, British, French and American elements. Particular attention is paid to the building's design and decoration, which are a blending of Romanesque, Gothic, and Arts and Crafts styles. Similarities and dissimilarities to Richardsonian Romanesque are noted. Note is also made of there being a co-benefactor of the library, Grace Redpath, who gave material support to her husband's efforts.

La bibliothèque Redpath occupe une place à part dans l'nistoire de l'Université McGill et de la bibliothéconomie canadienne. À son ouverture le 31 octobre 1893, elle était le deuxième pavillon universitaire autonome conçu tout spécialement comme bibliothèque au Canada et l'un des six pavillons parsemant le campus de l'Université. Grâce à la générosité et à la sagesse de son bienfaiteur, Peter Redpath, et au goût exquis et au talent de son architecte, Andrew Taylor, la bibliothèque est un chef d'oeuvre de la fin de l'époque victorienne et un remarquable exemple de planification d'une bibliothèque contemporaine. L'auteur situe Redpath et Taylor dans leur contexte historique pour illustrer la façon dont leur collaboration s'est soldée par une bibliothèque qui est un amalgame remarquable d'éléments canadiens, britanniques, français et américains. L'auteur décrit longuement la conception et la décoration de l'édifice qui allie les styles roman, gothique et "Arts and Crafts". Il fait ressortir les ressemblances et les dissemblances avec le style roman richardsonien. Il nous fait découvrir également que la bibliothèque a eu une cohienfaitrice en la personne de Grace Redpath, qui a appuyé matériellement les efforts de son mari.

"The Redpath Library one of the many gifts presented to McGill University by Peter Redpath 1893"

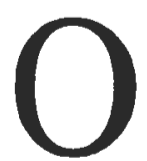

$f$ the generations of students and countless people who have walked past this memorial incised in stone on the north wall of Redpath Library, to mark its opening one hundred years ago, few have paid anymore heed to it than they have to the building and the man it commemorates. The grey limestone and exuberant romanesque architecture of the building bespeak another age with which few people today can relate. The original reading room is now a concert and reception hall. The old stack wing stretching to the south along McTavish Street is only a shell, its interior gutted and rebuilt with new floor levels which don't quite correspond with those of the windows. Overall, the building seems strangely out of place and dwarfed by the new wing of Redpath Library which was grafted on to its south and east walls in 1953, and by the concrete bulk of the 1969 McLennan Library, a bit farther south again.
In addition to being ignored and not understood, the old structure - like other library buildings of its generation - has been criticized and castigated by later generations of writers: a 1931 article referred to its lack of space and defects in plan $^{2}$; a 1951 study declared that the building's exterior "could not have encouraged honest architectural expression in Montreal"3; a 1953 article referred to academic libraries of the 1893 to 1917 period as "eclectic"4; and a 1977 study considered any academic library built before 1900 to be "primitive"

Rather than dismissing the 1893 Redpath Library out-of-hand or treating with smug condescension its various conversions as the inevitable fate of quaint old buildings, we should consider its important role in the life of McGill University, and in the development of Canadian, American and European librarianship. Like the 1953 wing and the 1969 McLennan Library, the 
1893 building is an important document and case-study in architectural form and function which brings us faceto-face with architectural imperatives generally and changing principles of library activity specifically.

Despite certain gaps in our knowledge, an amazing amount is known about the original Redpath Library its design and context - due partly to a number of studies of McGill buildings and of other Canadian and American libraries and partly to surviving archival and journal sources but mostly to a book commemorating its opening ${ }^{6}$. Taken together they permit the presentation of a precise and coherent narrative of the library's inception and historical role. This article will attempt, therefore, to place the people and circumstances surrounding its design, construction, and opening within an historical context. A description and evaluation of the building itself is given at the end of the article.

On November 12, 1891 Peter Redpath a wealthy Montreal businessman and senior governor of the University, sent a letter to the Chancellor, Sir Donald Smith, offering to construct a library for McGill. ${ }^{7}$ It would be on the land purchased recently at $\$ 50,000$ by J.H.R. Molson for the University along the east side of McTavish Street to the south of the Presbyterian College (Morrice Hall). As Molson and Redpath were old friends and as the letter specified that the new library's plans had already been prepared by the architect, Andrew T. Taylor, to fit on the purchased land, it can safely be assumed that the planning of the library had begun well in advance of the letter. Needless to say, the University accepted the offer quickly and gratefully.

Of Peter Redpath, very little is known beyond the main outlines of his life $e^{8}$. Born in Montreal on August 1,1821 and educated in England, he worked in his family's sugar refinery and other Montreal businesses for many years before retiring to England in 1879 to devote the rest of his life to various personal pursuits. His strong attachment to McGill University remained undiminished, however, as can be seen in his many generous benefactions and active membership on the Board of Governors.

Although no formal statement survives of why Redpath gave the library to McGill, the reasons for his doing so can be largely deduced from surrounding circumstances. First, the Principal, Sir William Dawson, was greatly admired by Redpath who built Redpath Museum (1882), as the first university museum building in Canada, to house the Principal's extensive palaeontological collections and to keep him from leaving McGill for another university". A separate library building for McGill had long been a goal of Dawson. Second, Redpath may well have wanted to ensure a suitable home for the great historical collections he was giving the University and which would be added to significantly by his widow. Third, there was a virtual vogue of benefactors building libraries for universities in the United States ${ }^{10}$. In an 1889 article on library architecture, ten academic libraries were reported to have been recently built or to be in the process of construction. Fourth, McGill's great rival, the University of Toronto, was on the verge of opening a separate library building, having lost its entire collection in a disastrous fire on February 14, $1890^{\prime \prime}$. Fifth, the curricular priorities of Canadian and American universities were changing. Undergraduate education was moving towards the liberal arts and graduate and professional programmes were being created $^{12}$. This German-American approach to higher education required strong library resources. Sixth, McGill was in desperate need of a library ${ }^{13}$. Although there is evidence of medical and general libraries dating hack to the 1840 s, Dawson was convinced that upon his arrival at the University in $\mathbf{1 8 5 5}$ there was no library and that only through his personal efforts was one begun. It is certainly beyond doubt that a direct line of succession exists from Dawson's library of 1855 in the High School on Dorchester Street to its next home with 1,500 volumes in his office in the Arts Building in 1860 , to the library room provided by William Molson in the West-wing of the Arts Building in 1862 . Molson's library had a capacity of 20,000 volumes which was reached around 1880 . With the library holding approximately 35,000 volumes by 1893 , additional rooms and shelving were needed to contain the overflow.

The official opening of the Redpath Library, on October 31, 1893, was clearly a grand occasion ${ }^{14}$. Their Excellencies the Governor-General and Lady Aberdeen were the guests of honour and were surrounded by other dignitaries on a platform at the east end of the reading-room with the audience seated in rows before them. Speeches were delivered by the 
Governor-General, the Lieutenant-Governor of Quebec, (J.A. Chapleau), Peter Redpath, Sir William Dawson, J.H.R. Molson (representing the Chancellor, Sir Donald A. Smith), Vice-Principal Alexander Johnson, the President of the Royal Society of Canada, (J.G. Bourinot) and by the Treasurer of Quebec (J.S. Hall), as a representative of the alunini. In his speech, Redpath made it clear that he was offering no deed of gift for the library as, by virtue of building it on University ground, he recognized that McGill now owned it. The Governor-General, after accepting a model in gold of the library's front door key, declared open a building whose exterior, except for its subsequent additions, looks much the same now as it did then.

Why does Redpath Library look the way it does? How was its interior organized? Was its grandiose exterior balanced by any concern for internal function, or was it built simply as a monument to the architect and donor? To these questions there are no easy or straightforward answers but rather a series of explanations whose relevance lies largely in the context of the times in which it was built. To begin with, it must be understood that when it opened in 1893, Redpath Library was one of scarcely a dozen freestanding library buildings in all of Canada. The others were the Parliamentary Library in Ottawa $(1876)^{15}$, the University of Toronto (1892) and a handful of public and other libraries, concentrated mostly in Ontario. Only in the twentieth century would library buildings become a typical part of the Canadian urban-scape, beginning with the 125 Carnegie Public Libraries built in the first two decades of the century ${ }^{16}$. Even as late as 1922 it is estimated that there were less than 600 libraries in the entire country with holdings of 5 million volumes ${ }^{17}$. Of these libraries, less than one-half would have been housed in separate buildings.

By comparison, in the United States the development of separately housed libraries - public, academic, and other types - took root more quickly and widely $y^{18}$. By 1900 , dozens of academic library buildings had been constructed, although the large majority of institutions of higher learning still housed their collections in buildings used primarily for other purposes. The first American academic library buildings were opened at the University of South Carolina in 1840 and Harvard in 1841. Harvard's Gore Hall was modelled after King's
College Chapel, Cambridge; typical of other academic libraries at the time, the books were shelved in alcoves around the circumference of the walls. Tables and seating for users were placed in the alcoves, but no separate work areas would be available for staff aside from a space in the middle of the library from which to supervise readers. Even though Harvard's chapel design was reinterpreted in star, cruciform, or octagonal shapes at various institutions, alcove shelving and seating would still be used and staff space neglected except to supervise readers. Another weakness of these early designs, perhaps the most serious, was the incapacity of expansion for shelving, seating, or any other activities. To judge from early photographs, the library in the West-wing of the Arts Building subscribed to the alcove shelving and seating of the first type of academic library architecture. The Parliamentary Library in Ottawa and the reading room of the Presbyterian College (Morrice Hall) at McGill were designed on the star plan with alcove shelving and seating.

During the $1870 \mathrm{~s}, 1880 \mathrm{~s}$ and $1890 \mathrm{~s}$ under the pressure of increasing enrolments, collections and users - along with evolving social, teaching and research needs - academic libraries in the United States entered a second phase and began experimenting with different solutions to space problems. In particular, there was a growing realization that library buildings had multifunctional uses. The public library movement, which had made enormous strides since the 1850 s, contributed greatly to this realization. Three components were specifically identified: collections, users, and staff. Rather than having them all jumbled together in one open space, it was realized that they must all be given separate areas with the possibility of coming together at specific points.

Various ideas presented themselves both in Europe and in the United States ${ }^{19}$. One approach was balconied stacks around open reading rooms topped by skylights ${ }^{20}$. These "cathedral" libraries were impressive to look at, but inefficient and wasteful of space. Two outstanding examples are the Peabody Institute (1875-1878) in Baltimore, Maryland and the Thomas Fisher Rare Book Library (1972) at the University of Toronto ${ }^{21}$. Another approach was collections housed in separate rooms, each devoted to separate subjects. Its finest nineteenth century exemplification occurred under the direction of 
William Frederick Poole at the Newberry Library (1888-1893) in Chicago ${ }^{22}$. Despite the difficulties involved in making such a system work effectively, it has proven very appealing in the academic milieu and made periodic comebacks in the form of subject divided libraries. In truth, however, these approaches were neither widely imitated nor universally embraced.

Two of the most significant clues to the future came from Europe, specifically Britain and France. One European contribution was the development of separate stack areas, closed to the public, distinct from reading rooms and placed behind, below or above them ${ }^{23}$. The best known nineteenth-century examples were the stack wings built adjacent to the reading rooms at the British Museum (1854-1857) in London and the Bibliothèque nationale (1858-1868) in Paris. These stacks were constructed as metal frameworks, independent of the outer masonry walls, supporting both the shelves and walkways between them; the shelving could be of either metal or wood. The first example in the Americas was the stack wing appended to Harvard's Gore Hall in 1877. Soon it was imitated by academic libraries everywhere. The other European contribution, which was imitated only later, came from la Bibliothèque Sainte-Geneviève (1844-1850) in Paris ${ }^{24}$. Its reading room was placed on the second floor away from street noise and congestion, and lighted by large windows close together along the wall. A separate, closed stack area was located on the first floor, not in a separate stack wing. This approach would provide the inspiration for Charles McKim's Boston Public Library (1888-1895) and for many early twentieth-century Canadian academic libraries ${ }^{25}$ such as those at Queen's (1923-1924), Western Ontario (1934) ${ }^{26}$, and British Columbia (1925) as well as for the Saint-Sulpice Library (1915) in Montreal.

The third significant clue to the future was American and also concerned the internal functioning of libraries but even more their external appearance and perception: the designs of Henry Hobson Richardson (1838-1886) ${ }^{27}$. Richardson, who received his architectural training in France, is sometimes credited with developing the first original American architectural style - Richardsonian Romanesque - which was notable for its exuberant and generous reinterpretation of Romanesque architecture: strong massing, round arches, short pillars, imposing roof lines unbroken along the ridge, roofs decorated with eye-brow windows, rock-faced nasonry usually in pink or red granite, tower-gable-arch entrances on an axis with the long side of the building, a nave-transeptapse arrangement of interiors, lavish use of fine materials and architectural details like fireplaces. Trinity Church, on Copley Square in Boston, is considered to he his masterpiece. These imposing buildings were usually designed with maximum attention paid to their decoration and to their exteriors. As for their interiors, they have elicited a wide range of reactions from detractors who consider them totally unfunctional and from supporters who consider them an important stepping-stone to twentieth century efficiency.

Although Richardson built only six libraries - one academic and five public - and designed several others, they hest exemplified his style in the minds of many people. All of them are remarkably handsome and charming, have survived to the present, and would exert an enormous influence upon the public and contemporary architects. They revealed his characteristic romanesque elements, his use of L-shaped design and his controversial interiors. Critics have argued that the alcove stacks were too dark and inconvenient, that staff space was inadequate and badly placed, and that the building designs did not lend themselves easily to expansion; others have argued that by virtue of distinguishing various library activities from one another and assigning them separate areas, no matter how inadequate they now seem, Richardson was providing the path for the future.

The influence of Richardson upon library architecture was crucial. The fact of the leading architect of the United States undertaking library commissions at the very time that the public library movement was in its first wave of success, and when academic libraries were assuming a new prominence did much to enhance their prestige. This prestige was assisted by the beauty of his structures, despite questions about their functionality. That Richardson should have emerged during the second, experimental, phase of American academic library architecture when librarians were themselves highly uncertain of the type of architecture and interior design best suited for libraries, placed him and other architects in the position of being able to do almost anything they wished. It is significant that in the years following upon Richardson's death, the library profession in the United States would 
pay much greater heed to standards and appropriate procedures for building libraries ${ }^{28}$.

The reality of Anerican academic library architecture during this experimental second stage is that it compromised. Monumental Richardsonian exteriors were narried to increasingly functional interiors based upon the tripartite division of users, collections, and staff. As the Victorian love of decoration and the picturesque died hard, impressive reading rooms and visual details such as artwork and fireplaces would be included. At the same time, however, separate fireproof stack wings, and indeed fireproof construction throughout were increasingly common. The two most important academic libraries built in the United States at this time were Cornell (1889) and Pennsylvania (1891 $)^{29}$. Both had Richardsonian Romanesque exteriors arranged in a basilica style with a nave, transepts, and apse. Their interiors included monumental reading rooms, separate steel stacks, entry ways with separate men's and women's cloak rooms, prominent circulation areas, separate staff work areas, periodical reading rooms, seminar rooms, and rooms for special collections. By today's standards, the deployment of space must be considered arcane, but by the standards of the time it was very good. More importantly, this functional division of space no matter how simplistic, led directly to twentieth century ideas of efficiency and functionalism.

If McGill was fortunate in having such a generous benefactor in Peter Redpath, it was equally fortunate in having as gifted an architect as Andrew Thomas Taylor ${ }^{30}$. Born in Edinburgh in 1850, Taylor displayed an early aptitude for architecture which he learned both at the apprenticeship and academic levels. In 1878 he was elected an Associate of the Royal Institute of British Architects for which he wrote two prize essays "Architecture in London in the Sixteenth Century" (1874) and "The Towers and Steeples Designed by Sir Christopher Wren" (1881). After working briefly in London he immigrated to Montreal in 1883 where he enjoyed a brilliant career until 1904 when he retired to England. The rest of his life was devoted to public service, and he became in time Mayor of Hampstead and Vice-chairman of the London County Council for which he was knighted in 1926. Upon his death in 1937 it was stated that he brought to bear in his public life an aesthetic perception and a sense of tradition qualities which are also observable in his architecture.

The nature of Taylor's Canadian architectural career was determined by two significant factors ${ }^{31}$ : his taste and training and his family connections with notable Montreal and McGill figures. His mother, Agnes, was the sister of Sir George Drummond, a future President of the Bank of Montreal, whose first wife, Helen, was the sister of Peter Redpath. Redpath's father, John, took as his second wife Jane Drummond, another sister of Sir George. As a result Drummond and the elder Redpath enjoyed a father-in-law and son-in-law relationship as well as a brother-in-law relationship, with Taylor and Peter Redpath thereby becoming cousins. In 1891, Taylor married Mary Elliott whose sister, Florence, was the wife of William Bell Dawson ${ }^{32}$ - son of McGill's principal of the day, Sir John William Dawson. Of themselves these connections might have counted for nothing, but taken together with Taylor's obvious taste and talent they did much to assist his career. Of course, he received numerous commissions from the Bank of Montreal and for buildings on the McGill campus. In addition, however, he built many private homes as well as commercial and noncommercial structures for other clients. During his twenty-one years in this country, between 1883 and 1904, he and his firm, Taylor and Gordon, became leading lights of Canadian architecture.

Concerning his architectural style and preference, we have the evidence of both Taylor's buildings and discourses. Although his journal articles and public lectures are far too numerous and diverse to be discussed here, two books should be mentioned: The Towers and Steeples Designed by Sir Christopher Wren... (1881) $)^{33}$ and his "appreciation" and other contributions to Alexander Galletley's Ancient Towers and Doorways... in Scotland (1896) ${ }^{34}$. As for his buildings they reflected the following styles: Romanesque, Gothic, Tudor, Flemish, Renaissance, Palladian, and Queen Anne.

The predominant artistic and design ideas of British nineteenth-century art and architecture embraced decoration and historicism - an eclectic approach which found inspiration in the styles of earlier ages and adopted them to contemporary use ${ }^{35}$. A repudiation of eighteenth-century neoclassicism in favour of what were 
considered to be vernacular styles, such as Romanesque and Gothic, became hallmarks. Pugin's Gothic revival buildings and the writings of Ruskin fuelled the ideologies and the designs. At the same time, however, there were three significant minority movements within this mainstream approach: Pre-Raphaelitism, the Aesthetic Movement, and the Arts and Crafts Movement of William Morris. While sharing a love of the decorative and historical, they deplored the excessive opulence and crassness of the mainstream. They were also motivated by a social consciousness which was concerned with raising the level of public taste, thereby improving people's conditions of life. While these three minority movements shared certain themes and decorative motifs, their true bonds were a way of working and an attitude to life rather than a style; design and its execution were seen as a unified whole. A fundamental dichotomy in their thinking revolved on whether inspiration should come primarily from the historical or from the observation of nature. In their architecture, a characteristic design feature was an L-shaped buildng. All three movements were composed of individualistic reformers and missionaries. The successor to these movements, in the 1890's, was Art Nouveau - a popular style - which was led by nonmissionary individualists, who embraced mass production techniques, and looked to a highly-stylized nature, not history, for inspiration. Its most notable design characteristic was the whiplash motif. A variety of influences could be seen in its architecture, one significant style of which was Beaux-Arts - a reworking of classicism.

Within this context, Taylor emerges as a member of the eclectic mainstream, with an enthusiasm for historically inspired architecture. At the same time, he was influenced by the minority movements, particularly the decorative ideas of Aestheticism and of Arts and Crafts and their concern that construction and decoration be seen as a unified whole. Taylor's dual background of family and McGill connections and of architectural and social ideas are nicely captured in two small gifts he made shortly before and after his arrival in Montreal ${ }^{36}$. In 1881 he gave a copy of his The Tower and Steeples to Peter Redpath with a note expressing the hope that "it may not be altogether without interest". In 1886 he sent another copy to the McGill library with the following note:
It may have some little interest from the fact that these towers and spires are disappearing year by year before the insidious demands of commerce and a stern utilitarianism.

Taylor is neither the first nor the last person to combine within himself scholarship, ambition, artistic sensibility, personal advantage, and a sincere desire to better the world. In his work both at McGill and elsewhere these qualities became manifest.

Of his buildings a sufficiently large number survive, or have surviving pictorial records, for one to appreciate both their range of styles and quality of design. Four were built adjacent to the McGill campus, of which three survive, that are of particular interest ${ }^{37}$. On Milton Street, just east of the campus, is the Marlborough Apartments (1900) built of red brick in a Queen Anne Style - much beloved of the Aesthetic and the Arts and Crafts movements. Around the corner on University Street is the Diocesan College (1895-1896) built in red brick and stone in a Gothic style with a Flemish tower. On the south-west corner of St. Catherine and Mansfield Streets is the red stone West End Branch of the Bank of Montreal (1888), in a Romanesque style. Standing formerly at the south-east corner of Sherbrooke and Metcalfe Streets, where the Scotia Tower is now, was Sir George Drummond's red stone mansion (1889-1930), generally considered to have been the grandest private residence on Sherbrooke Street during its golden era ${ }^{38}$. Its design was an interesting blend of Gothic and Romanesque; contemporary photographs suggest that its windows were neither pointed nor rounded, but rectangular.

Concerning his McGill career, Taylor is probably the single most important architect in the University's history. By 1896, he was responsible for six of the eight buildings on the campus, the exceptions being the Arts Building, constructed in stages between 1839-1843 and 1860-1862 to the design of John Ostell ${ }^{3.9}$, and Redpath Museum built by A.C. Hutchison and A.D. Steele between 1880 and $1882^{40}$. Between 1890 and 1896 Taylor built: Macdonaid Engineering (1890), Workman (1891), Macdonald Physics (1892), Redpath Library (1893), Medical (1894), and Macdonald Chemistry and Mining (1896). The Engineering Building and much of the Medical Building were destroyed by fire in 1907; the Workman Building has 
been so modified as to prevent easy appreciation. All were constructed of Montreal limestone, cut usually in a plain or dressed fashion. The Medical, Workman, Engineering and Chemistry buildings were all more or less symmetrical in style and showed distinct Renaissance influences. By comparison, Physics and Redpath - one designed to be a library and the other subsequently converted to one - are romanesque and asymmetrical. A book published to commemorate the opening of the Engineering and Physics buildings on February 24, 1893 provides a detailed analysis of both buildings, complete with photographs ${ }^{41}$. Unlike the similar book published to commemorate Redpath Library's opening, there was no article by Taylor, and no attempt to justify or explain the aesthetic and design qualities of the two buildings. This suggests that neither Taylor nor Sir Willian Macdonald, the benefactor, either wished or felt it necessary to justify these aspects of the buildings.

Writing in 1925, Ramsay Traquair dismissed Taylor's buildings as American compared with the British Georgian style of those constructed on the campus before and after him. ${ }^{42}$ Such dismissal seems most inappropriate, as architectural historicism and the rejection of neo-classicism were equally prevalent at this time in both Britain and the United States. Indeed, Percy Nobbs and Bruce Price who succeeded Taylor as McGill's most notable architects were also influenced by historicism. ${ }^{43}$ It may be that Traquair was referring to the supposedly Richardson Romanesque styles of the Macdonald Physics and Redpath Library buildings. Caution is advisable, however, as there is evidence to suggest that Richardson was as much influenced by British neo-Romanesque architects - such as E. W. Godwin and William Burges - as he was by the French proponents under whom he studied. ${ }^{4}$ Nor should it be forgotten that even for Ruskin, the Romanesque architecture of Pisa was his favoured style ${ }^{45}$. Within Canada itself there were many examples of Romanesque architecture dating from at least the 1870s: St. Andrew's Presbyterian Church in Toronto (1874$1875)^{46}$, Windsor Station in Montreal (1887-1889) ${ }^{47}$, and Taylor's own West End Branch in Montreal (1888). Finally, one should not overlook the close collaboration between 1889 and 1896, with Henry Beaumont (b. 1853), the Arts and Crafts sculptor and carver whose work in stone, wood, and plaster decorated many of Taylor's buildings including those on the McGill campus ${ }^{48}$.

While 1893 was the peak year of Taylor's McGill career with the opening of three of his buildings, it was also the year which marked the beginning of his decline. The Chicago World's Fair occurred that year which with its "White City" architecture heralded the arrival of Beaux-Arts architecture into the America ${ }^{49}$. This new style, with its links to Art Nouveau, held little interest for hin. It is significant that he did not accept the inspiration of Charles McKin's Boston Public Library (1888-1895) which, with its Beaux-Arts expression, sits resolutely across Boston's Copley Square from Richardson's Trinity Church ${ }^{\mathrm{s}}$. It is ironic, therefore, that one of Taylor's last commissions, and the one that some people think may have led him to give up his architectural practice, was the reconstruction of the Head Office building, on Place d'Armes, of the Bank of Montreal. In the end, however, he served only as the contractor carrying out the Beaux-Arts designs of McKim, Mead, and White. Appreciating that the time for his combination of historicism linked to an Aesthetic and an Arts and Crafts sensibility was now over, Taylor retired to England.

Peter Redpath and Andrew Taylor, as donor and architect, were both fully aware that their new library was highly decorated and both were equally anxıous to avoid any possible criticism because of it. They were also quite concerned to demonstrate that they had taken into account all the new ideas on library architecture relating to functionalism and efficiency. Their concern, not only to do the right thing but to show that they had done so, may well have been motivated by their having planned and supervised the design and construction of the new library themselves. Of course, they did request suggestions from the university community, solicit advice from individuals, consult with a committee of the Board, and visit some libraries. But in fact, Redpath did not actually give the university money to build a library using its own architectural and contracting procedures as would normally occur in the late twentieth century. Rather Redpath with his architect, in the manner of benefactors of the day, designed and built the library according to their ideas, turning it over to McGill only upon completion.

In his short memoir of the benefactor, Sir John 
William Dawson quotes approvingly from an obituary, which appeared in the Times (London), that Redpath spent $\$ 75,000$ building a library and museum for McGill ${ }^{\text {s. }}$. As this would have been the equivalent of $\$ 375,000$ (Canadian) - the pound then being worth $\$ 5.00$ - and as in a quotation from the Canadian Gazette (London) Redpath Museum was said to have cost $\$ 140,000$, the Library may be assumed to have cost $\$ 235,000$. Certainly, Dawson says nothing to dispute such an assumption. If this figure is true, Redpath Library would have been, at the time, the most expensive academic library of its size in either the United States or Canada. It had a stack capacity of 140,000 volumes. The University of Toronto's library, opened the year before, cost approximately $\$ 70,000$ for a building of similar size, design, and stack capacity. ${ }^{52}$ The major differences are that its Romanesque style was that of a basilica - nave, transepts and apse - and that it is relatively free of internal or external decoration and carving. In the United States, academic libraries of comparable and even larger size cost less: Yale, with a stack capacity of 200,000 volumes, cost $\$ 125,000$; Cornell, with a stack capacity of 475,000 volumes, cost $\$ 225,000$; and Pennsylvania, with a stack capacity of 85,000 volumes which would rise to 512,000 volumes when the stacks were completed, cost $\$ 200,000 .^{53}$ Unless there is some error in the amounts quoted, or unless the building cost also included the capitalization for the endowments, it must be assumed that the reason for Redpath Library being so expensive was due to its elaborate decoration. Indeed, it is difficult not to think that the decoration accounted for a significant proportion of the cost of the building .

It is in this light, therefore, that Redpath's thoughts on the library, spoken at its opening, should probably be considered:

It is the result of as much care and attention as the architect and myself knew how to bestow upon it. The plans of many other libraries were examined, and many other Iibraries were visited both by myself and the architect, with a view to arriving at the best possible plan for this building on this site. The newly appointed librarian, too, gave many valuable suggestions in matters of detail. I know that we have not attained perfection; but experience will show how far we have advanced towards that end. In no case has utility been sacrificed to architectural or aesthetical effect, yet I believe that the architectural design and the aesthetical effects have met with the general approbation of the comparatively few persons who have hitherto had an opportunity of studying them. ${ }^{54}$

In a complementary way Andrew Taylor expressed the architect's task when he mused:

How to obtain on the site a commodious, convenient, well planned, well lit library, which would also allow of easy expansion, and be at once collegiate, dignified, monumental and beautiful. There are many magnificent, hoary and time-honoured library buildings in the Old World, in which the precious legacies of the past have been preserved and treasured up; but wants change with the ages, and in the altered and special circumstances of today some other arrangements than these old buildings afford seemed desirable. In the United States, great interest has recently been taken in the planning and fitting up of library buildings, and considerable ingenuity and skill have been displayed in the designing of such... Convenience of arrangement and suitability for its purpose, combined with substantiality and solidity of construction were the desiderata; afterwards came in the elements of beauty, proportion and grace, and it is hoped that in some measure, all of these have been attained without the sacrifice of one to the other. ${ }^{55}$

This circumstance of the architect and donor assuming full responsibility and authority for the design and construction of the new library along with their concern lest its aesthetic qualities overshadow its functional and practical convenience deserves much closer scrutiny. It is unfortunate, therefore, that the documentary evidence for further analysis is highly incomplete. There is no indication of the libraries visited, the people consulted, or the results of consultation with the committee of the Board of Governors. In one of his articles, however, Taylor did 
speak of the assistance received by various unnamed American librarians. ${ }^{56} \mathrm{He}$ also spoke of the help and co-operation of Charles H. Gould (1855-19 19) who had been appointed University Librarian in 1892 and who, because of his lack of library experience, spent his first year studying and visiting libraries. The qualities that would make him such an outstanding librarian were apparently evident from the beginning. ${ }^{57}$

How then did Redpath and Taylor get their ideas on building a new library? According to Redpath they examined plans and visited libraries; according to Taylor they found inspiration not in European but in American examples. In the years following upon the death of H.H. Richardson - which coincide with the period when Redpath Library was being designed American librarianship engaged in a very public debate on library architecture. Of course, in this as in any debate, there were acrimonious personal and ideological confrontations, but in addition some very sane and sensible enunciations of principles and procedures were to emerge. Although there is no evidence of the donor and architect reading or hearing any specific debates or discussions, it is quite clear that directly or indirectly they were exposed to them and were able to reap much positive benefit as a result. In two articles from 1890 and 1891 issues of Library Journal, then as now a leading publication, comments appeared which are reflected in the completed building and in the writings of Redpath and Taylor. The first article presented principles of library architecture agreed upon generally by librarians ${ }^{58}$ :

"A library building should be planned for library work."

- "Every library building should be planned especially for the kind of work to be done and community to be served."

- "The interior arrangement ought to be planned before the exterior is considered."

- "No convenience of arrangement should ever be sacrificed for mere architectural effect."

- "The plan should be adapted to probabilities of growth and development."

"Simplicity of decoration is essential in the working-rooms and reading-rooms."

- "A library should be planned with a view to economical administration."

- "The rooms for public use should be so arranged as to allow complete supervision with the fewest possible attendants."

- "There should be as much natural light as possible in all parts of the building."

- "Windows should extend up to the ceiling, to light thoroughly the upper part of every room."

"Windows in a book room should be placed opposite the intervals between bookcases."

Aside from the fact that Redpath Library was obviously designed both internally and externally to be a showcase, the various principles of efficiency and functionality were all observed, in particular the last three recommendations on natural lighting. The windows both in the reading room and the stack wing are very prominent and rise to the ceiling.

In the second article, the author in one paragraph outlines "current ideas" on library architecture and design which conform remarkably to Redpath Library" it should be designed in a modified romanesque style, with reading and seminar rooms, exhibition areas, a separate stack wing which can be extended, and a basement mail room connected with a cataloguing room above adjacent to which is the head librarian's office. His advocacy of fireproof construction throughout and a stack capacity five times greater than the current size of the collection also found expression in the building. Although there is no evidence that these specific articles were read, it is clear that their message was received and translated into the planning of McGill's new library.

Peter Redpath survived the opening of his library by only a few months, dying on February 1, 1894. His last great exertions had occurred the previous fall when he had overseen the completion and opening of his library. The minute book of the Committee to organize the opening ceremonies speaks of the various postponements, of Taylor racing into meetings directly from the construction site, and of Redpath chairing the meetings and making virtually all major and minor decisions. ${ }^{60}$ On the evening of October 31, 1893 following the opening ceremonies - a conversazione, or entertainment, was held in the reading room, presided over by the Governor-General and Vice-Reine and by Peter and Grace Redpath. Tickets for the event were eagerly sought. It should be mentioned that the event was held despite the architect's insistence that the great 
hall was not meant for evening events ${ }^{61}$. It is ironic that in the forty years since 1953, its use has been largely in the evening.

A memorial service for Peter Redpath was held in the library reading room on February $6,1894^{62}$. One hundred year later, in 1993, we feel shy about the expression of religious faith and are inclined to dismiss it as either cant or, worse still, hypocrisy. The eulogy by the Rev. Dr. MacVicar, minister of the Montreal church attended by Redpath, and the prayer by the Rev. George Cornish reflect the firm belief that Peter Redpath was a good, kind, and philanthropic man. In fact, religion plays a key role in understanding Redpath, his contemporaries, and the library itself. Peter Redpath, Sir John William Dawson ${ }^{63}$, and Andrew Taylor - benefactor, principal, and architect - were all Presbyterians whose community so influenced McGill and English-speaking Montreal one hundred years ago. Dawson was almost as notable for his religious as for his scientific publications; Taylor began his career in England as a church architect and taught ecclesiastical architecture at Montreal's Presbyterian College. Redpath's kindness and philanthropy - including the building of Redpath Library - were religiously motivated. His humility - also religiously based showed itself in his insistence that the library not be called Redpath Library but the University Library ${ }^{64}$. Only after his death was it officially named after him.

In many ways the library's great reading room - the Redpath Hall of today - can be seen as an outstanding piece of ecclesiastical architecture. Many commentators, including those of the 1890 s, have discussed the links between the design of churches and libraries ${ }^{65}$. In the case of Redpath Hall, it is eastward facing with great windows to let in the morning sunlight - in the European tradition of church architecture. Carved in stone, on the capitals of the buttresses at the east end, are the four Evangelists. The stone carvings around the main entrance are clearly patterned after those of medieval Scottish churches. The new organ in the gallery at the hall's west end, behind which is another great set of windows, continues the ecclesiastical theme. The aesthetic, academic, and religious elements of the interior are perhaps best exemplified in the verse from the Bible carved in wood with raised letters in an Arts and Crafts style by Henry Beaumont, which used to hang at the entrance to the recessed fireplace but now hangs at the east end below the windows: "Happy 1s The Man That Findeth Wisdom and The Man That Getteth Understanding. ${ }^{166}$ Redpath and Taylor built better than they realized and provided McGill University with a great hall which, at one and the same time, possesses the qualities of a library reading room, a concert hall, a reception room, and a university chapel.

Given this context and the wide range of influences, how does one evaluate the aesthetic and design qualities of Peter Redpath's 1893 library? That its exterior is Romanesque is beyond question as even the architect, Andrew T. Taylor, was prepared to admit:

The style adopted is a free treatment of Romanesque, which lends itself to the requirements of such a building, as being at once dignified and yet picturesque. ${ }^{67}$

As Taylor, like architects of every age, adapted and reinterpreted the prevailing styles of the day in his own vocabulary, the question becomes how closely does the library conform or not conform to the principles of Richardsonian Romanesque. Not surprisingly, strong similarities and disimilarities can be observed. Like Richardson, Taylor favoured a massive effect of stone and an L-shaped building comprising the reading room and stack wing. The arrangement of the three windows on the reading-room's east wall is remarkably similar to the window arrangement in the transepts of Trinity Church, Boston. The roof line is imposing and unbroken along its ridges. Eyebrow windows were placed on the roof of both wings. There is a towergable-arch entrance on the building's long side leading into the middle of the reading room. The interior also revealed certain distinctively Richardsonian touches. There was a very large reading room whose nave-like quality was balanced by tiny transepts: a bay-window to the east of the main entrance and a large recessed fireplace - an inglenook - facing it on the south wall which was removed when the 1953 extension was built. ${ }^{8}$

There were, however, many variations from the Richardsonian style - some minor and some major. The building's L-shaped design reflects the Arts and Crafts style as much as it does Richardson's. Although the chapel-like nave and transepts were present, there 
was no apse - a semi-circular recess at the end of a building - but then not all of Richardson's libraries possessed one. The gable over the main entrance was a very meagre atfair; indeed the main entrance-way was really a porch which was not entirely in sympathy with Richardsonianism. The tower was to the right of the door, not the left as in Richardson's libraries; and the turrets were long and angular not short and round. The outer stone-walls were of Montreal grey limestone not Richardson's pink granite; and except for the basement level, the stones were of dressed-work, not rock-faced. Perhaps the most striking external variation from Richardson are the windows which, rather than being designed as ribbons or slits, were quite large and admitted a great deal of light into the stacks and the reading room. The reading room windows on the north and south walls are rectangular, rather than rounded, and are placed between buttresses which suggest not the Romanesque but rather the Gothic. Nor is there a discernible Richardsonian influence in the towers at the east end of the reading room, whose purpose is obviously to admit additional light into the hall.

It is in the interior, however, that the greatest variation from Richardson occurred and where the library's adherence to the professional ideas and practices of the time is most visible. A tripartite division of space for collections, users, and staff similar in concept, if not in detail, to that employed at the Cornell and Pennsylvania libraries was used for Redpath Library. This division of space, which designates separate areas for the three components but brings them together at salient points, and which had been hinted at by Richardson, represented a fundamental break with the past and maintains important theoretical links with much twentieth-century library architecture. At the core of this new approach was the separation of the users from the books which were placed in a four-storey fire-proof stack wing with a capacity of 140,000 volumes. It was designed to permit southward expansion towards Sherbrooke Street; the first extension completed in 1901 was also designed by Taylor, the second in 1922 was by Percy Nobbs ${ }^{69}$. The steel stack wing, complete with a book-lift, its own staircases, polished oak shelving, and floors of irongrating and rough plate glass had levels seven to eight feet high. It was made to McGill's specifications by the Library Bureau of Boston, a commercial firm, and was inspired by the stacks of the British Museum, the Bibliothèque nationale, and Harvard's Gore Hall. A "special muniment vault for the care of precious books and muniments" was also provided, the exact location of which is not indicated.

Separate space for users was provided in many ways. The main floor contained a periodicals reading room and cloak rooms. In the basement, which was mostly above ground, there were five studies or seminar rooms, as well as lavatories. On the upper floor there was a gallery for displays, overlooking the west end of the reading room. It was flanked on the north side by a "Professors' room", or faculty reading room, and on the south side - over the stack wing - by a large hall whose ceiling was the inside of the peaked roof. There was uncertainty as to the use to which this latter room would be put, except to suggest it could be used for displays and exhibitions. The centrepiece for users was clearly meant to be the "great reading room" with its east to west axis and windows on all four sides which was 110 feet long, 43 feet wide, and 44 feet high. Although it had book cases built flush against the wall to accommodate reference books, it was spared both the alcove and cathedral stacks of previous ages.

Separate space for staff was also provided. In the basement there was a caretaker's apartment, and a mail delivery room which was connected by both a lift and staircase to the cataloguing room above. Located on the library's main floor at the west end below the gallery, the cataloguing area was separated from the main reading room by an ornamental glass screen and by card catalogue cases whose drawers opened either into the staff area or into the reading room. The University Librarian's office was adjacent to the cataloguing room. Outside these staff areas, at the southwest corner of the reading room and adjacent to the stack entrance, was the circulation desk referred to as "the attendant's counter for the distribution of books". This was the magical point, where collections, users, and staff were expected to come together. By the standards of the late twentieth-century, these provisions for books, readers, and librarians may seem quaint, simplistic, or even inadequate. But in fact, compared with previous ways of organizing library interiors these provisions represented a great leap forward and placed the Redpath Library in the vanguard of progressive thinking. A direct ancestral link with 
late twentieth-century library architecture can clearly be discerned. A marked advance upon the interiors of Richardson and his predecessors had been accomplished.

The architect was particularly proud of the technical sophistication of the new library. In addition to the stacks being entirely fire-proof, the rest of the building was nearly so:

The whole of the main floor is of steel beams and porous terra cotta arching. The other floors and the roofs, where not of this material, are of solid oak beams, and flooring on the slow combustion principle. The stairs are of iron and slate... The roofs are of blue Rockland slates and copper. ${ }^{70}$

The building was heated by hot water radiators which, in the main reading room, ran lengthwise down the middle forming a natural boundary between the men's and women's study tables. The library was wired for electricity with the original brass chandeliers still hanging from the reading-room ceiling. In addition the study tables had lamps with double green shades. The floors were covered with cork carpeting to deaden the sound.

A significant topic of concern in any study of the building must be its decoration, both interior and exterior. A profusion of carvings enliven the outside limestone walls and can still be discerned despite the soot from Montreal's polluted atmosphere: gargoyles and tracery abound everywhere. Carved above the main entrance are Peter Redpath's motto and crest: Ne timeas recte faciendo and an ostrich with a key proper in its beak. Carved also at the entrance, on the left, is a lion holding a book to represent the strength of knowledge, and on the right the McGill arms. The double doors, of polished oak with wrought-iron grill work and fittings, have carved in the middle bottom section of each the letters RLB - Redpath Library Building. All the sculpting and carving for the building - inside and outside whether on stone, wood or plaster were Celtic in style and done by Henry Beaumont in an Arts and Crafts manner.

Inside the library, more decoration awaits the eye.
Attractive plaster mouldings abound. The reading room was painted in soft green with gold trim, and the entrance hall and staircase in soft red. Two decorative features dominate the reading room. The first is the high open timber roof with its double hammer beams ornamented by grotesque animals and a few carved heads one of whom looks like Peter Redpath and the others are suspected to be portraits of the architect and the carver. The second is its windows. Those at the side are glazed and leaded in geometrical patterns. Panels were left in them for quotations and inscriptions such as "reading furnishes the mind only with the materials of knowledge, it is thinking makes what we read ours". Much more vivid are the windows, by Clayton and Bell of London England, at either end of the room, the gifts of Grace Redpath, the donor's wife. ${ }^{n}$ Painted on them were the medallion portraits of the great masters, or secular saints, of various subjects. The five windows at the west end are dedicated to law, history, philosophy, astronomy, and medicine. The three at the east end are dedicated to art, poetry, and music. Taken in toto, these interior and exterior decorations are completely in sympathy with nineteenthcentury attitudes and aesthetic values.

What then do all of these diverse influences and styles add up to? Although the exterior of the building can be superficially designated Richardsonian Romanesque, the real designation is more properly Taylorian Romanesque/Gothic. Taylor's architecture was too sophisticated and too influenced by a wide variety of aesthetic and practical considerations for his buildings ever to be in any style other than his own. As for the library's interior organization and arrangement, they were very much within the mainstream of leading American professional opinion on how the inside of a library should look in 1893; by the standards of the day, it was practical and functional. In its decoration, there reigned both inside and outside the building an Arts and Crafts reworking of Celtic designs. In short Redpath Library is an admirable example of late Victorian eclecticism, historicism, aestheticism, and functionalism. Its blending of Canadian, British, French, and American influences makes it distinctly Canadian. It can even be seen as a precursor of Canada's Chateau Hotel architecture.

As a final note, it should be pointed out that the interior of Redpath Hall contains two memorials 
commemorating its benefaction. The first, placed originally in the great reading room beside the circulation desk but now in the foyer facing the main door, is a marble bust of Peter Redpath by the noted British sculptor, Sir William Reynolds-Stephens. ${ }^{72}$ Flanking either side of it is an inscription carved in wood with raised letters in the Arts and Crafts style of Henry Beaumont, which reads: "Peter Redpath Born Montreal Augt. 11821 Died Chislehurst Eng. Feb. 1, 1894 This Bust And Canopy Were Presented To The University By A Few Of His Friends And Admirers In The United Kingdom. This Edifice One Of Many Noble Gifts Was Presented To The University By Peter Redpath Opened On The 31st Octr. 1893."

The second memorial is much more subtle and less easily noticed. Along the bottom of the great east windows there was later added a strip of stained glass containing the portraits of Peter and Grace Redpath, which reminds us that Redpath Library has not one but two benefactors. For Grace Redpath, as much as her husband Peter, deserves credit for the library. ${ }^{73}$ She supplied the money for the great windows at the east and west ends of the hall and for the 1901 stack wing. She increased the endowment for the building's maintenance, and added signiticantly to the Redpath Tracts collection. The inscription in glass accompanying the portraits seems particularly appropriate and reminds us that as long as Redpath Hall endures, it will serve as a monument to the love that Peter and Grace Redpath shared with one another: "Vitream Istam Cura Sua Pictam Collegio Mariti Gratia Amato Dono Dedit Gratia Redpath": "Grace Redpath gave this painted glass window to the College at her own expense in commemoration of her beloved husband."

\section{Notes}

1. The author acknowledges with gratitude the assistance received from the Canadian Architecture Collection, Blackader-Lauterman Library, McGill University; the Canadian Centre for Architecture, Montreal, particularly Renata Guttman; Prof. Rhodri W. Liscombe, University of British Columbia; and Professor Faith Wallis, McGill University.

2. Philip J. Turner, University and College Libraries of Canada; Their Planning and Equipment (Montreal: McGill University Publications, 1931), 8.

3. David H. Molson, "The Redpath Library, McGill University, Montreal, P.Q.," (Undergraduate term paper). McGill University. Blackader-Lauterman Library. Canadian Architectural Collection. File on Redpath Library.

4. H. M. Reynolds, "University library buildings in the United States, 1890-1939" College and Research Libraries, v. 14, no. 2 (April 1953), 149-157, 166

5. Jerrold Orne, "Academic library buildings: a century in review," Libraries for Teaching, Libraries for Research: Essays for a Century, ed. by R. D. Johnson. (Chicago: American Library Association, 1977), 146.

6. Opening of the New Library McGill University, Montreal Containing the Addresses Delivered on the Occasion with a Description of the Building; Some Points in the History of the University; in Memoriam. October 31st 1893. Montreal, 1893.

7. Ibid., 9.

8. Allan Bell, "Munificent, wise, and thoughtful gifts", Grace and Peter Redpath and the Redpath Tracts." To be found elsewhere in this volume (pp. 45-67). And, "William Prynne at McGill... a descriptive catalogue of the ... Redpath Tracts." Research Project, Graduate School of Library and Information Studies, McGill University, 1992. See introduction. "Peter Redpath (1821-1894)" A Srandard Dictionary of Canadian Biograpnhy; Canadian Who Was Who, ed. by Sir Charles G. D. Roberts. (Toronto: Trans Canada Press, 1938), v. 2, 372-373. 
9. Stanley Brice Frost, McGill University, for the Advance of Learning (Montreal: McGill-Queen's, 1980), v. I, 243.

10. Addison Van Name, "Report on library architecture," Library Journal (Conference Issue), v. 14 (1889), 162-164.

11. Robert H. Blackburn, Evolution of the Heart; a History of the University of Toronto Library up to 1981 (Toronto: University of Toronto Library, 1989), Chapters 9-14. And, "Dewey and Cutter as Building Consultants," Library Quarterly, v. 58, no, 4 (October I988), 377-384.

12. Jurgen Herbst, The German Historical School in American Scholarship; a Study in the Transfer of Scholarship. Ithaca, Cornell University Press, 1965.

13. Peter F. McNally, "McGill University Libraries," Encyclopedia of Librany and Information Science. (New York: Dekker, 1976), v. 17, 311-320.

14. Opening of the New Library. 11-23

15. Kenneth Binks, Library of Parliament, Canada ([Ottawa| KCB, 1979), 27.

16. Margaret Beckman, The Best Gift; a Record of the Carnegie Libraries in Ontario (Toronto: Dundurn, 1984), 19.

17. Canada. Dominion Bureau of Statistics. Anmual Report on Education Statistics in Canada, 1922 (Ottawa: King's Printer, 1924), 167.

18. Robert B. Downs, "The role of the academic librarian, 1876-1976," Libraries for Teaching, 115 126. Arthur T. Hamlin, The University Library in the United States, its Origins and Development (Philadelphia: University of Pennsylvania Press, 1981), Chapter 10. Edward G. Holley, "Academic libraries in 1876," Libraries for Teaching, 1-33. David Kaser, "The American Library Building, 1870-1890," Journal of Library History, v. 21, no. 1 (Winter, 1986), 60-71.

19. W. Jordy, American Buildings and Their Architecture: v. 3, Progressive and Academic Ideals of the Turn of the Twentieth Century (New York:
Doubleday, 1976), v. 3, Chapter 7 "The Beaux-Arts Renaissance: Charles McKim's Boston Public Library." This chapter is essential reading for the topic.

20. Ibid., 321-323.

21. Blackburn, 223.

22. Jordy, 324-325.

23. Ibid., 326-327, and Kaser, 64.

24. Jordy, 333-344.

25. Turner, 12, 20, 24.

26. Margaret A. Banks, The Libraries at Westerm, 1970 to 1987 ... (London: University of Western Ontario, 1989), 11.

27. Kingston Heath, "Henry Hobson Richardson," Encyclopedia of Architecture (New York: Wiley, 1989), v. 4, 264-273. Jeffrey Karl Ochsner, H. H. Richardson, Complete Architectural Works. Cambridge, Mass., MIT Press, 1982. James F. O'Gorman, H. H. Richardson; Architectural Forms for an American Society. Chicago: University of Chicago Press, 1987. W. H. Pierson, "H. H. Richardson," Macmillan Encyclopedia of Archirects (New York: Macmillan, 1982), v. 3, 558-575.

28. Orne, 142-143.

29. Kaser, 66-70. "Andrew Thomas Taylor," The Canadian Men and Women of the Day, ed. by H. J. Morgan. (Toronto, Briggs, 1912), 1086.

30. "Sir Andrew (Thomas) Taylor," Who Was Who (London: Black, 1941), v. III, 1327-1328. "Andrew Thomas Taylor" 5 leaves. Canadian Centre for Architecture. File on Andrew Thomas Taylor. "Andrew Thomas Taylor," Royal Canadian Academy of Arts: Exhibits and Members 1880-1979 (Toronto: University of Toronto Press, 1981), 397-398, John Bland, "McGill 's late great Victorian architect: Sir Andrew Taylor," The Fifih Column, v. 2, no. 1 (Fall, 1981), 32-34. "Taylor and Gordon," 4 p. McGill University. Canadian Architectural Collection. File on Andrew Taylor. Prepared for Susan Wagg by R. Hill, 
December 26, 1983 to be published in The Biographical Dictionary of Architects in Canada, 1800-1950.

31. Donald MacKay, The Square Mile: Merchant Princes of Montreal (Vancouver: Douglas \& McIntyre, 1987), 60.

32. "William Bell Dawson," The Canadian Men and Women of the Time, ed. by Henry James Morgan. (Toronto: Briggs, 1898), 253-254.

33. Andrew T. Taylor, The Towers and Steeples Designed by Sir Christopher Wren, a Descriptive Historical and Critical Essay with Numerous Illustrations. London: Batsford, 1881.

34. Alexander Galletly, Ancient Towers and Doorways being Representarions and Restorations of Mason crafi Relating to Celtic and Norman Ecclesiology in Scotland... with Appreciation and Descriptive Letterpress by Alexander Taylor. London: David Nutt, 1896.

35. Elizabeth Aslin, The Aesthetic Movement; Prelude to Art Nouveau (New York: Excalibur, 1969). Chapters 2 and 10 are particularly helpful. The Earthly Paradise; Arts and Crafts by William Morris and His Circle from Canadian Collections. Toronto, Art Gallery of Ontario, 1993. The introductory chapters by Carole Silver and Rosalind Pepall are very helpful. Encyclopedia of Arts and Crafts, the International Arts Movement (1850-1920). London: Headline, 1989. The Introduction and Chapter 2 are very helpful.

36. Both copies are in the Blackader-Lauterman Library, McGill University. Photocopies of the dedications are in the Taylor file at the Canadian Centre for Architecture.

37. Andrew Thomas Taylor (in the file at the Canadian Centre for Architecture).

38. Mackay, 133-138.

39. Ellen James, John Ostell; Architect, Surveyor (Montreal: McCord Museum, McGill University, 1985), 35.

40. Rhodri W. Liscombe, "The Peter Redpath
Museum, an Architectural Analysis" Fontanus; from the Collections of McGill University, v. 1 (1988), 4958.

41. Formal Opening of the Engineering and Physics Buildings, Mc Gill University, Montreal, February 24th, 1893. (np, np, nd.)

42. Ramsay Traquair, The Buildings of McGill University. Montreal: McGill University Publications, 1925.

43. Susan Wagg, Percy Erskine Nobbs; Architect, Artist, Craftsman. Montreal: McGill-Queen's Press, 1982.

44. Henry-Russell Hitchcock, Richardson as a Victorian Architect (Baltimore: Barton-Gillet, 1966), 11-13. J. Morduant Crook, William Burges and the High Victorian Dream. London: Murray, 1981.

45. Nikolaus Pevsner, Ruskin and Violet-le-Duc: Englishness and Frenchness in the Appreciation of Gothic Architecture (London: Thames and Hudson, 1969), 26-27.

46. Eric Arthur, Toronto, No Mean City, 3rd. ed. (Toronto: University of Toronto Press, 1986), 167.

47. Marc H. Choko. The Major Square of Montreal (Montreal: Meridian, 1990), 156-157.

48. Andrew Thomas Taylor (in the file at the Canadian Centre for Architecture).

49. Bland, 34 .

50. Jordy, 314.

51. Sir J. William Dawson, In Memoriam Peter Redpath, Governor and Benefactor of McGill University... (Montreal: "Witness," 1894), 13-16.

52. Blackburn, 86-93.

53. George W. Harris, "The new library building of Cornell University," Library Journal, v. 14, no. 4 (April 1889), 121-124. Van Name, 167, 168, 171. 
54. Opening of the New Library, 11.

55. Ibid., 25, 28.

56. Andrew T. Taylor, "The new library building," McGill Fortnightly, v. II, no. 3 (November 10, 1893), 51-52.

57. Peter F. McNally, "Scholar librarians: Gould, Lomer, and Pennington," Fontanus: From the Collections of McGill University, v. 1 (1988), 95-104.

58. Charles C. Soule, "Points of Agreement among librarians as to library architecture," Library Jourmal (Conference Issue), v. 16 (1891), 17-19.

59. H. M. Utley, "Report on library architecture," Library Journal (Conference Issue), v. 15 (1890), 1214.

60. McGill University Archives. RG40 Library. Minutes of Meetings of Library Committee SubCommittee Charged with making arrangements for the opening of the new library 1893. v. 18. C214.

61. Ibid., September 19, 1893. Sections 3-7.

62. Opening of the New Library, 38-39.

63. Peter R. Eakins, "Sir John William Dawson," Dictionary of Canadian Biography (Toronto: University of Toronto Press, 1990), v. XII, 230-237.

64. McGill University Archives. RG40 v. 18, C214, October 4, 1893. "Disposition of Redpath Hall" Section 6.

65. William Frederick Poole, [Discussion of Charles Soule's paper "Points of Agreement among librarians as to library architecture." ], Library Journal (Conference Issue), v. 16 (1891), 99.

66. Proverbs 3:13.

67. Opening of the New Library, 28.

68. Richard Pennington, "The Redpath Library extension," McGill News, v. 35, No. 1, (Winter, 1953), $7-9$.
69. Wagg, 40-41.

70. Opening of the New Library, 28.

71. Ibid., 12, 28,

72. "Sir William Reynolds-Stephens 1862-1943," The Modern British Paintings, Drawings and Sculpture, by Mary Chalmot. London, Oldbourne, 1964. p. 547-548.

73. Bell, "Munificent, wise, and thoughtful gifts." to be found elsewhere in this volume (pp. $47 \mathrm{ft}$ ). 